\title{
KING ARTHUR'S DIN DRAITHOU AND TREVELGUE, A CORNISH CLIFF-FORT
}

Keywords: King Arthur, Celtic place-names, Cornwall, St Carannog

\begin{abstract}
Traditions of Carannog, a Welsh saint of about the year 550, appear in his vita prima written in the twelfth century and surviving in a copy of the thirteenth (his vita secunda, a mere fragment, is not discussed here). The vita prima is best known for what it says on Arthur. Carannog leaves Wales, encounters King Arthur in south-west Britain, eventually gains his support, and is given lands near Arthur's stronghold of Din Draithou. The location of that fortress has been obscure, but it must have been famous, because it figures in the ninth-century Historia Brittonum, as also the Glossary of Cormac (d. 908), bishop-king of Cashel in south-west Ireland.
\end{abstract}

In this paper we attempt to identify Din Draithou, arranging the material in four parts. We begin with discussion of vita prima sancti Carantoci, before going on to Historia Brittonum and then Cormac's glossary; in the last section, analysis of the three enables us to identify Din Draithou as Trevelgue, the ancient fort on the cliffs near Newquay, a resort on the north coast of Cornwall, in south-west England. It will not have been anywhere on the coast of Somerset (the county south-west of Bristol), as is often thought. If we are correct in taking Din Draithou as Trevelgue, we underline the importance of the site in Dark-Age Cornwall, and show aspects of Carannog's life as based on fact. The implications of this for Cornish archaeology and history are obvious. One should note that this very identification was suggested in 1994 by the Cornish archaeologist Charles Thomas (1928-2016) in his And shall these mute stones speak? (as the author discovered while writing this paper). Thomas's volume has been much criticized and this proposal has effectively been ignored. Although one can take issue with many of Thomas's remarks on toponyms (such as 
his placing St Patrick's Bannaventa in Cumbria, when it must have been at Banwell in Somerset/Avon), on Din Draithou and Trevelgue he was nevertheless right. His memory deserves credit for that.

\title{
Vita prima sancti Carantoci
}

Of the three texts, the Latin life says most about Din Draithou, although its misrendering in Acta Sanctorum (1680: 584-587) as "Diudraithov" indicates problems for researchers. The life itself was summarized in about 1772 by Philip Perry (1720-1774), Rector of the English College, Valladolid. Because Perry's history of early Christian Britain was not published until 2009, his comments (made in a survey of Celtic hagiography, and with information from other sources) are worth quoting in full.

\begin{abstract}
St Carantac was a holy British priest of royal extraction and contemporary to St Winwaloc and St Patrick, the British Apostle of Ireland, for according to his short Life in Bolland, which though in some things fabulous, appears very ancient, he was contemporary to Caton, King or Duke of Cornwall, and cousin of Fracan, father to St Winwaloc. He was son of Keredic, King of Keretic [Ceredigion, in south-west Wales], or Glamorgan, and the same perhaps as Corotic, the invader of Ireland, mentioned in the Life of St Patrick. If so, St Carantac made some atonement for the crime of his father. Being priest, he crossed over to Ireland and was assistant to St Patrick in his laborious apostleship in that kingdom, but after some time returned to Britain and died there about the end of the fifth age. He is honoured the $16^{\text {th }}$ of May. (Carrera, Carrera 2009: 134)
\end{abstract}

No scholar now associates Carannog with Patrick. Perry also failed to note that (according to the life) Carannog died in Ireland, where he was buried. His "some things fabulous" is shorthand for the story of a dragon, which had devastated Arthur's territory and was yet tamed by Carannog. A step forward of sorts was a new edition of the life by Rees (1853: 97-99). It has been abused by all commentators for inaccuracies of transcription, but nevertheless prompted research, even if Haddan and Stubbs (1869-1871: 44, 158-160) curiously ignored it in their catalogue of Welsh hagiography, after noting it previously. An accurate edition of the passage did not appear until the end of the century, when Lot (1900) offered the correct reading Dindraithou, comparing it with Cair Draithou in Historia Brittonum and Din Tredui in Cormac's glossary. He noted that Acta Sanctorum (1680) had "Diudraithov", with the Bollandists using a transcript sent by Sir William Dugdale, while Rees had “Dindrarthou”, neither of which makes sense. Lot's topographical guesswork was inferior to his editing. After describing the Cornish hill-fort of Castel-an-Dinas (eight miles east of Newquay, on Cornwall's north coast), he declared "Il me semble que nous avons là la Cair Draithov ou Din Draithov demandé" (Lot 1900: 1-10). Unfortunately, Lot knew almost nothing of Celtic philology. If he had been able to translate Dindraithou, he could not have taken it as Castel-an-Dinas. 
The life received full attention from Baring-Gould and Fisher (1907-1913). They gave an account of Carannog's origins in the Ceredigion region of Wales and how, while escaping southwards across the Bristol Channel, he lost his portable altar. It washed up on the shore and fell into the hands of Arthur, the local ruler, who eventually returned it to Carannog. Baring-Gould and Fisher noted that "Arthur held his Court at the time in Dindraithou. This is probably Dun Tradui, the three-fossed fortress erected by Crimthan Mór (366-378) to hold down the British, when he held dominion from Alba [Scotland] to the Ictian Sea (the English Channel). This is spoken of by Cormac in his Old Irish Glossary" (Baring-Gould, Fisher 1907-1913: 12). Citing the edition of Stokes (1862) and comments of Egerton Phillimore, they accepted Dun Tradui as "in the lands of the Cornish Britons", its being as well "the Cair Draitou" amongst the Twenty-Eight Cities of Britain listed by Historia Brittonum. As for Carannog's "city of Chernach", this they thought either Crantock in Cornwall or Carhampton in Somerset (Baring-Gould, Fisher 1907-1913: 78-90). But neither of these two is correct, for the text puts the place in Ireland, where Carannog died. As for Dindraithou, we know that it was an arx or citadel situated on the coast and looking towards Wales. Somerset and Cornwall have contended for its location until now.

Plummer (1910: cxxiv) alluded to the life as regards Carannog's time in Ireland. Lloyd (1911: 259) made no mention of it in his history of Wales, merely speaking of Llangrannog (Carannog's birthplace) as in the district of Caerwedros, Ceredigion. Williams (1912) cited the life from London, British Library, MS Cotton Vespasian A. XIV (Williams 1912: 301), further noting how in Welsh-Latin hagiography Arthur is represented as "a prince whose heart was given to the Church and the saints" (Williams 1912: 349). Plummer later mentioned Carannog as perhaps the St Cairnech of Irish tradition, whose feast is also on 16 May (Plummer 1925: 206). Kenney (1929: 180, 352) gave details on Cairnech, whose name he understood as Irish for "Cornishman", which is not what Carannog means.

Analysis of the vita prima was provided by Chambers (1927). He told how Carannog set his altar adrift on the Severn Sea, and it "floated to the realm of Cato and Arthur, who dwelt in Dindraithov". Carannog came to the south-west and, after an incident when he tamed a dragon which had devasted the district of Carrum, received back his altar from Arthur, who "gave Carrum to the saint in perpetuity". After building a church there, Carannog once more set his altar adrift "and it landed at the port of Guellit. Here too a church was built and town called Carrov" (Chambers 1927: 82-83, 246-247). Chambers put the serpent story on the coast of west Somerset, Carrum being Carhampton, Guellit the stream at Williton, and nearby Dunster, with its great castle, probably being Dindraithov. Unlike Lot (1900), whose edition of the passage he reproduced, Chambers did not locate it in Cornwall, despite recognizing Carannog as patron of Crantock, near Newquay.

Expert philological knowledge came with the glossary of early Welsh poetry by Lloyd-Jones (1931-1963: 111, 358). In addition to explaining Carannog as "dear one, beloved", he put (emended) din draetheu in Cornwall, not Somerset, and related it to the Dun Tredui of Cormac's glossary and the Cair Drait(h)ou listed by Historia 
Brittonum as one of Britain's Twenty-Eight Cities. Other opinions were expressed by Canon Doble (1932: 14-15) in a pamphlet on St Carannog, where he confidently put Din Draithou at Carhampton, on the coast of west Somerset between Minehead and Watchet. Doble's prestige as a hagiographer here eclipsed the claims of Cornwall for generations. Appearing in a rare pamphlet, his case took time to be noticed. Foster (1935-1937) made no reference to it in an early paper, instead citing Arthurian associations for Castel-an-Dinas and Lot's belief that it was Dindraithou, together with Chambers's advocacy for Dunster, Somerset. Far from Wales, an encyclopedia referred to Carannog as "Originaire d'Irlande, où il est appelé Cairnech", despite clear statements on his birth in Ceredigion (Vies des Saints 1936-1957: 327). In Wales itself, again without mentioning the saint, Lloyd (1937: 20) described Carannog's native region of Caerwedros, with Castell Caerwedros near Llangrannog as "an ancient centre of the district" (but perhaps not its original capital). A late Irish stanza on Cairnech calls his community at Tuilén (= Dulane in County Meath, north of Dublin) a British one, implying that Cairnech and Carannog were the same man (Carney 1943: 6).

Fundamental progress came in 1944, with an accurate edition of the vita prima by Wade-Evans, which he believed was written in Ceredigion at "about the beginning of the twelfth century" (Wade-Evans 1944: xi-xii). It is of interest to Arthurian scholars as a text on Arthur predating Geoffrey of Monmouth's Historia Regum Britanniae of the mid-113os. Wade-Evans made no comment on where Din Draithou was, but we reproduce his translation on Carannog's taming the dragon and bringing it into the hall of Arthur and Cadwy, showing how the hagiographer enjoyed a story.

Then Carannog went and prayed to the Lord, and immediately the serpent came with a great noise like a calf running to its mother, and it bent its head before the servant of God like a slave obeying his lord with humble heart and with sidelong glance. And he placed his stole about its neck and led it like a lamb, nor did it raise its wings and claws. And its neck was like the neck of a bull of seven years, which the stole could scarcely go round. Then they went together to the citadel and greeted Cadwy, and they were welcomed by him. And he led that serpent down the middle of that hall and fed it in the presence of the people, and they tried to kill it. He did not allow it to be killed after which Carannog took it to the gate of the citadel and ordered it to depart. It was never seen again. (Wade-Evans 1944: 140-147)

The passage here names Cadwy, not Arthur, as lord of the stronghold. He was less famous than Arthur, implying that he was the real ruler of Din Draithou. Genealogies cited below show him as the great-grandson of Constantine of Dumnonia, who was amongst the five kings denounced by Gildas in the spring or summer of 536, when a volcanic cloud from the Americas appeared over Britain. That would put Cadwy and Carannog in the very late sixth century.

Research up to the Second World War was summarized by Chaussy (1950). In the post-war period came a new impetus from Bowen (1954: 89-91) on the cults of the saints, including maps to show churches under Carannog's patronage in south-west Wales, Cornwall, and north-west Brittany, if at first without mention 
of Somerset. Despite that, Chadwick (1954) took the vita prima (regarded as Breton, not Welsh) to represent Arthur "as ruling jointly in Somerset" with Cato or Cadwy. Intriguing, if not relevant to present purposes, is a "very perplexing text" preserved corruptly in the vita prima. It is a hymn to Carannog, dated "to the sixth or early seventh century" and praising the holy works in Ireland of one who was "brave and faithful, fitted to minister in peace, for in wonderful manner he was like the angels" (Carney 1955: 407-412). From a popular historian we hear how Carannog's altar "ran aground near 'Dindraithov', Arthur's citadel", and how Arthur thereafter gave "Carrum" to the saint. "The location of this tale is between the Quantocks and Exmoor. Dindraithov is Dunster" (Ashe 1957: 90-91). Jackson (1959) thereafter made a dismissive comment (but with useful bibliography) on Arthur in Welsh saints' lives of about 1100, where the king is "usually troublesome to the saint at first but is overcome by a miracle". Of such texts by "monkish writers", he thought it was "idle to look here for history" (Jackson 1959: 1-11). Their Arthur, a chieftain and dragonkiller, is certainly unhistorical. But genuine data may be found if one seeks them. Lloyd was also sceptical. Dating Carannog as perhaps of about 550, he noted his associations with Llangrannog in Ceredigion, Carhampton in Somerset, Crantock in Cornwall, Dulane in Ireland, and Carantec (near Morlaix) and other sites in Brittany. Because all these places observed his feast on 16 May, Lloyd considered that "the same missionary-monk is denoted". Beyond that "there is little which can be relied upon in the pious fragments of biography which have been handed down" (Lloyd 1959: 67). There is a better bibliography in Bibliotheca Sanctorum, drawing a line under work up to the 1960 os (Mostardi 1962).

That decade itself saw little progress on Carannog. The conflicting genealogies for him were edited, that in the vita secunda taking him back via the Ceredig of Ceredigion to St Anne, "quam dicunt esse consobrinam Marie Uirginis" (Bartrum 1966: 26). Pennar Davies (1966: 60) made the following strange observation on the negative picture of Arthur in saints' lives. The saints were of royal descent, but Arthur (who lacked royal blood) had by force made himself overlord of their dynasties. Hence the animus against Arthur, an upstart, in lives written by disciples of these saints. The historical map for the period tends for Somerset against Cornwall. It shows the Willite as a stream there running into the Bristol Channel, and Carrum to the west of it (Map 1966). Jackson (1959), its consultant on Celtic place-names, must in part have accepted the Somerset case. Carannog's Welshness is underlined by the volume containing his life. It is now London, British Library, MS Cotton Vespasian A. XIV, and is attributed to the scriptorium either at Brecon or Monmouth, both in south-east Wales (James 1967: xxiv-xxv). Under the heading of "Fact" (though no such thing), Ashe again asserted that Carannog came to "Dindraethou (Dunster, in Somerset), where Arthur reigned as junior colleague of a prince named Cadwy" (Ashe 1968: 27-57). An outline history of Dulane, associated with St Cairnech/Carannog, dates him to about 450 (Gwynn, Hadcock 1970: 33). That cannot be correct. Carannog's meeting with Cadwy puts him in the sixth century, not the fifth.

Comment of the 1970 may be dealt with quickly. The archaeologist Leslie Alcock commented on Arthur's negative image in Welsh hagiography. The life of 
Cadog, of the early 109os, "portrays him as lustful and perverse"; the life of Padarn, of about 1120, "shows him as an avaricious tyrant" (Alcock 1971: 53). The vita prima, in contrast, treats him gently. Doble's confidence in Carannog's Somerset connections appears in a comment on how the vita prima "shows personal knowledge of St Carantoc's church of Carhampton and of Somerset legends about him" (Doble 1971: 135, n.119). Bowen used traditions of Carannog from Dulane, Llangrannog, Pembrokeshire, Crantock in Cornwall, and "churches dedicated to him at Carantec, near Quimper, and at Trégarantec, south-east of Lesneven" (Bowen 1972: 78) to show how he and other Welsh peregrini "used the western seaways linking Wales to Cornwall, Devon, Somerset, and Brittany" (Bowen 1972: 79). Morris was also of the Somerset party. He spoke of how "in north-western Somerset, in Dumnonia, 'Cato and Arthur ruled, living in Din Draithov"' (Morris 1973: 121). He identified it as the stronghold constructed by Crimthann of Munster, "styled king of Ireland and Britain in the genealogies" (Morris 1973: 158), who "had visited Britain and built there the royal fort of Din Tradui" (Morris 1973: 645). Bowen (1977: 72) thereafter repeated his list of churches in Ireland, Wales, Cornwall, and Britanny dedicated to Carannog. But no word on Somerset or Din Draithou.

A new seriousness entered research in the 1980 s as concerns bibliography and place-name studies. For the first, the vita prima was listed by Lapidge and Sharpe (1985: 37) for its manuscript, editions, and commentary. The second is represented by the dictionary of Padel (1988). It gives Crantock, on the north coast of Cornwall, as first recorded in Domesday Book of 1086 and named after its patron. Born in Ceredigion, "on his way to Cornwall he assisted King Arthur by taming a dragon in Somerset. He also has dedications in Brittany" (Padel 1988: 74). Significant here (as we shall see) is Lancorru, recorded in 1302 as the name of the churchtown (= the village where a Cornish parish church is situated), with -corru seemingly a pet-version of Carannog. In Crantock to this day is a house called Langurra, representing the form (Padel 1988: 74). Farmer's (1987: 74-75) Oxford dictionary adds a detail on Carannog and the Cornish hagiologist Nicholas Roscarrock (1549?-1634?). Discussing British missionaries in Ireland, Dumville asks whether Carannog really existed "must be open to some doubt", while implying that detailed research might resolve the question (Dumville 1993: 140, n.48).

An instance of such research is supplied by Padel (1994). Despite inaccuracies, it deserves attention. He says this on the vita prima. Carannog left Wales and met King Arthur in Somerset, with whom his relations were "amicable" but businesslike. Carannog rid Somerset [sic!] of a dragon, Arthur restored his altar to him, and he received the arx of Carrum, which is Carhampton, near the coast of west Somerset. "Immediately after the dragon episode, the action of this brief Life moves to Cornwall, without any indication of the change. Arthur seems to be envisaged as an authority there too" (Padel 1994: 1-31). Carannog's altar arrives at the mouth of the Guellit, where he founded another monastery called Carrov. Padel's next comment is crucial. The stream at Crantock is the Gwills (anciently Willit). (Although Padel does not see the implications of this, a connection with Williton in Somerset can thus be ruled out.) As for Carannog's second monastery of Carrov, this represents 
his pet-name, Padel giving the Cornish name of the churchtown as Langorrou. It should be cited with the proposal, hidden away in an endnote, of the late Thomas on Din Draithou as "perhaps" Trevelgue, nearby Newquay and "between two beaches" (Thomas 1994: 325). Together, their information will lead us to discovery of Din Draithou, fort of the Gael and one of Britain's Twenty-Eight Cities.

Of more recent studies, Higham's (2002) has nothing on St Carannog. WickhamCrowley (2002: 103-104) cites Jeff Rider on Arthur and the Welsh saints. But this helps little on the cult of Carannog. Gloria Torres Asensio, repeating the surmise of Lot, thinks that Dindraithou can be identified "con las ruinas de una fortaleza actualmente Castell an Dinas" (Torres Asensio 2003: 135), which she thinks overlooks Cape Cornwall (her geography is skewed, the hillfort being nearly forty miles from Cape Cornwall, in the far west of the county). Better is Martin Aurell of Poitiers. He cites Padel's (1994) paper, observing of Arthur and Carannog that the king "lui donne également les terres de Carrov (Crantock, nord de Cornouailles?), où l'on construit une église" (Aurell 2007: 73).

There is a complete chapter on Carannog in a recent collection of essays. It gives Dindraithov as apparently in Somerset and goes on to a "somewhat incoherent doublet of the same story" of an altar cast ashore, this time "at the mouth of the river Guellit with the saint in this case building a monastery called Carrov". Despite noting Arthur's ruling in Somerset as "unusual although not unique", it cites Charles Thomas for the view that Dindraithov "seems to have been in Cornwall, not Wales" (Jankulak 2007: 116-148), with Thomas in a footnote hesitantly proposing the Iron Age promontory fort of Trevelgue, north of Newquay. As for Dinn Tradui, Thomas was sure that that was a different place. He proposed Moel Trigarn in Pembrokeshire, Wales. No mention is made of Cair Draithou in Historia Brittonum.

There is now a full account of Llangrannog's name, noting its namesake in Cornwall (Owen, Morgan 2007: 261). The cult of Carannog is again discussed by Jankulak (2009), but this time in the context of other saints commemorated near Crantock. Perry's English summary of the vita prima in Acta Sanctorum (1680) was at last published in 2009, nearly two and a half centuries after it was written (Carrera, Carrera 2009: 134). Dindraithou was taken in 2011 by the present writer as Dunster, Somerset (Breeze 2011). The whole purpose of this essay is (of course) to set that right. Padel also states that Arthur in the vita prima "gives the saint a written charter of land in Somerset in perpetuity, and additional land further west, presumably at the parish of Crantock in Cornwall" (Padel 2013: 31-32). His emphasis is not on topography, but on how Arthur appears in the text.

Most recently, Higham locates Carannog's encounter with Arthur seemingly at Carhampton, which would thus "place the action in Somerset" (Higham 2018: 242). He thereby shows how the dispute of Cornwall versus Somerset for the lands of Carannog remains unresolved. At the close of this paper, we shall reject the claims of Somerset with a firm hand. Carannog's monastery was in Cornwall. The notion that he worked in Somerset has no substance. It should permanently be dismissed. 


\section{Historia Brittonum}

A list of twenty-eight British cities in the ninth-century Historia Brittonum has allured and misled British antiquaries from the tenth century to the twenty-first. As early as the 940s, the redactor of the Historia's Vatican recension added five names to it, unaware that some of them were duplicates of forms already too corrupt for him to recognize. Some of the toponyms, all with Old Welsh cair 'stronghold', are easily recognized. Cair Ebrauc is Eboracum or York; Cair Lundem is London; Cair Ceint is Canterbury, Kent. Others have defied the ingenuity of investigators. That has been so because many of the most obscure ones are not Roman cities at all, but monasteries in south-east Wales and the border, as recorded in the twelfth-century Book of Llandaff. 1 It seems that when a copy of Historia Brittonum, compiled about 829 in north-west Wales, reached the south-east of the country, a local scholar added a list of "cities" with special emphasis on local monasteries, but including as well certain British strongholds, like Dumbarton in Strathclyde or Craig Gwrtheyrn in Carmarthenshire, Wales. One of the forms added by him is Cair Draithou. We here add to what has been said of it already.

Like the rest of the list, it intrigued scholars. The Anglo-Norman writer Henry Huntingdon (d. 1155) copied it with others into his Historia Anglorum, but did not try to locate it. His list was copied again by John Leland (d. 1552), antiquary to Henry VIII, who again had no suggestion on where Cair Draithou was. Leland's list after Henry of Huntingdon was published in the eighteenth century, including Caer Ebrauc or York, Caer Kent or Canterbury, Caer Luel or Carlisle, and the unlocated Cair Draico, corrected to Cair Draito (Leland 1774: 289-290). The last two represent Cair Drait[h]ou.

Henry of Huntingdon and Leland could give no site for this item. Nor could Williams (1929-1931), despite reference to Mommsen's 1894 edition of Historia Brittonum. For original Cair Draitou or Draithou, Williams merely gave Henry of Huntingdon's Kair Draiton. It will be seen that Leland's Cair Draico and its superscript correction to Cair Draito show further corruption of this form. The failure over a millennium and more to identify the Twenty-Eight Cities is indicated by a comment of the Chadwicks in Cambridge. They considered the list as perhaps much older than the ninth century when Historia Brittonum was compiled. They believed that Gildas in the earlier sixth century may have had it "in his mind when he wrote (cap. 1) that there were twenty-eight cities in Britain" (Chadwick, Chadwick 1932: 281). Yet we shall see that Cair Draithou was unlike anything that the Greeks and Romans would call a city. The catalogue was further discussed by Jackson (1938), who noted the connection with Dindraithou and Din Tredui, and made a crucial observation: that draithou is (with initial mutation) the Old Welsh for 'beaches'. The significance of this has not been grasped. Morris's (1980: 40, 80) translation of Historia Brittonum merely has "Draithou Fortress".

\footnotetext{
1 The twenty-eight "cities" are identified on this basis in an appendix to this essay.
} 
There is, however, now a full account by FitzPatrick-Matthews of the North Hertfordshire Museum, Hitchin. Because it contains useful points but also some misconceptions, it may be quoted at length. He calls Cair Draithou "a puzzle", despite the parallels in Historia Brittonum and Cormac's glossary. He phrases the evidence for its whereabouts as follows. Carannog's altar "washed up at the mouth of the River Guellit in the district of Carrum/Carrou (Carhampton, where the parish church is dedicated to this saint), ruled by Cato and Arthur from Dindraithou". Because the "River Guellit is the River Willett" four miles east of Carhampton, some have taken Dindraithou as nearby, yet "this is not necessarily the case, although it was clearly somewhere in the south-western peninsula". Cormac's Din Tradui means 'triple-ditched fort'; there being no such forts within ten miles of Carhampton, "it is possible that an Old Welsh original has been rendered into a more recognizably Irish form. He adds Jackson's fundamental (and neglected) comment that Din Daithou means 'fortress of beaches' in Old Welsh. He concludes that, if so, "the author of the Historia Brittonum has again projected a post-Roman place-name back into the Roman past" (FitzPatrick-Matthews 2015: 1-19).

The discussion is a curious mixture of logic and its opposite. It ignores Padel's observation of 1994 that the stream at Crantock, Cornwall, is the Gwills, and was once called Willit. FitzPatrick-Matthews states further that the list is the work of Historia Brittonum's author, when it is a later addition. He also tries to force the twenty-eight toponyms into the preconceived notion of their being Roman cities. It would be more scientific to identify them first and deduce their nature from that. Most fundamentally, he sees nothing strange in the text's double narrative, with Carannog crossing the Severn Sea to the country of Cadwy and Arthur, "dwelling in Dindraithov", where a dragon ravages "the land of Carrum", and his second voyage "to the mouth of the Guellit", where he builds a monastery "called Carrov". We may infer that two episodes have been made out of one. Such a hypothesis will remove all difficulties from the text.

\section{Cormac's Glossary}

In addition to Irish references to Dind Tradui or Dun Tredui already given are as follows. Hogan (1910: 345 ) assembled them from various manuscripts but said no more on where the stronghold was than "in Britain”. Watson translated Cormac's account with the comment that "Criomhthann's activities in Britain were probably confined to the south-west of England" (Watson 1926: 217). Despite Cormac's words on Crimthann's ruling from Scotland to the England Channel, "there is nothing to show that he was ever in Scotland" (Watson 1926: 217). O'Rahilly thereafter offered an interesting example of a scholar changing his mind. On Dind Tradui he began by accepting the explanation by Rudolf Thurneysen of it as "Fort on the far side of the Dee" (O'Rahilly 1946: 210), the great river of North Wales and Cheshire. In an additional note he corrected himself, noting the equation with Dindraithov and Cair Drait(h)ou. He thought its exact situation "quite uncertain", despite Lot's 
arguments for Castel-an-Dinas in Cornwall and Chambers's for Dunster in west Somerset (O'Rahilly 1946: 497). Jackson (1953: 57-58) offered cogent remarks on Dind Tradui of Irish tradition as St Carannog's Din Draithov "in Cornwall", and perhaps the Din Drait(h)ou of Historia Brittonum. The Crimthann son of Fidach described as king of Britain "was very likely himself a legendary person" (if dated by the Irish to the fourth century after Christ), but Jackson still believed that Cormac used "genuine tradition" from Britain for "Irish overlords in Cornwall and south-west England in the fourth and fifth centuries" (Jackson 1953: 155-156). Jackson's equating of the three was accepted by Chadwick, who yet followed Doble for Din Draithou as surely "the district round Carhampton on the coast of Somerset between Minehead and Watchet" (Chadwick 1958: 29-120). The conquests in Britain of the legendary Crimthann are put into quite another context by Byrne, who takes them as showing how the Irish "had settlements in Cornwall" (Byrne 1973: 183-184). The impasse between Somerset and Cornwall is again evident.

\section{Place-names, Cornwall, and a solution}

In our last part we draw conclusions from the above. Jackson in 1938 explained Din Draithou as Old Welsh for "Stronghold of Beaches". Padel in 1994 pointed out that the Gwills at Crantock was once the Willit, and that Carannog's supposed second monastery of Carrov was Crantock, as proved by the local form Langorrou. In the same year Thomas proposed hesitantly in a footnote that Din Draithou might be the nearby cliff-fort of Trevelgue, though he was convinced (on dubious philological grounds) that it could not be the Dun Tredui of Cormac, for which he preferred a location in West Wales.

Let us look at what has been written on Crantock and Trevelgue. Crantock is now a mere village, looking north across the estuary of the Gannel to the modern seaside town of Newquay. But in the Middle Ages and later it was a port. "It had considerable trade with Wales and Ireland, and even as late as the eighteenth century Welsh coal for Truro was landed at Penpoll and Trevemper, both within the parish" (Elliott-Binns 1955: 197). This flourishing trade, withering after the estuary silted up, accords with Carannog's journeys from Wales and Ireland. Welsh coal in the days of King George followed the routes of a Welsh evangelist of the sixth century.

On the other side of Newquay, two miles north-east, is the promontory fort of Trevelgue. "The headland is defended by a complex of seven lines of banks and ditches, in addition to a natural cleft in the rock which separates the fortifications into two groups. Within the defences are a series of hut circles whose finds suggest occupation from the Iron Age to the Dark Ages. The site overlooks an excellent natural harbour with a flat beach" (Pevsner 1970: 229). To the north is a second beach, two miles long. The fort that stands on a cape is situated between two beaches, its harbour giving it obvious strategic advantages. It is elsewhere described as a "great fort" with "four-close set ramparts defending the narrowest part of the promotory, an inner enclosure and 
an outer annex" showing it as "a work of several periods" (Fox 1973: 141), even though the protracted delay of reports on excavations in 1939 long prevented archaeologists from saying much more. Nevertheless, "amphora sherds" in then-unpublished material indicated occupation during the early Christian period (Fox 1973: 198). Dark (1994: 94) considers it as possibly one of the "high-status native sites" of the south-west inhabited from the fourth century into the sixth, adding that activity "had probably ceased" there "by the eighth century at latest" (Dark 1994: 220). In the days of Cormac (d. 908) it was deserted, though evidently not forgotten. On the basis of "luxury imports" (Koch 2007: 104) found there, such as fragments of grass-marked pottery and (bringing wine from the Mediterranean) amphorae, Trevelgue is now again put with important "secular settlements" of south-west Britain (Koch 2007: 160). No surprise, therefore, if the Welsh remembered it as the court of Arthur and Cadwy, where Carannog led a dragon like a lamb into the royal hall.

As for Carhampton and other places in Somerset, their coup de grâce is easily given. Medieval hagiographers were not exacting on place-name interpretation and modern scholars (with less excuse) are often no better. Let us give examples. An obvious one concerns Maserfelth, where St Oswald of Northumbria was killed in 642 by the Mercian king Penda, as described in book three of Bede's Historia Ecclesiastica. The battle has for centuries been located near Oswestry ("Oswald's tree") in north-west Shropshire. Yet Williams pointed out long ago that Bryn Cae Meisyr and other local toponyms would put Maserfelth south of Welshpool, Powys, where the Roman road from Wroxeter enters Wales (Williams 1935: 209). The same point was made previously by Max Förster and Holthausen, working in Germany (Needham 1966: 36). Unaware of their argument, the late Gelling (1978) likewise dismissed the claims of Oswestry. It is certainly "Oswald's tree"; but there is no reason whatever to take him as the king, or understand his tree as a Christian cross. Citing the church of St Werburgh at Warburton, Cheshire, a place originally unconnected with the saint, Gelling maintained that the same thing had happened at Oswestry, if feeling sure that her suggestion would come as "a shocking heresy to the people of that town, and they will doubtless continue to believe that Oswestry is the place where St Oswald, the Christian King of Northumbria, was killed by Penda, the heathen King of Mercia” (Gelling 1978: 186-187).

St Werburgh had no historical link with Warburton, Cheshire. St Oswald had no historic link with Oswestry, Shropshire. With them in mind, we turn to St Carannog and Carhampton, Somerset. The crucial evidence here is the River Guellit. Carannog's altar came ashore at its mouth on its second voyage, and founded the monastery of Carrov nearby. There are two reasons why we can and must discount a connection with Somerset. First, Padel in 1994 showed that the Gwills stream at Crantock was once called Willit, and that Carrov is represented in Langurra, the name of Crantock's churchtown. Second, the River Willett is thought to have a name of English origin, not a Celtic one. So there is no need whatever to take it as the Guellit of the vita prima. It seems clear as regards Carhampton, four miles west of Williton, that its name in the earliest form Carrum "by rocks" (an English form) has been confused with Carrov, Carannog's monastery at Crantock, Cornwall. This may be deduced from 
the new Cambridge dictionary, where all these attestations are set out (Watts 2004: 115-116, 165, 681-682). As St Werburgh was brought to Warburton and St Oswald to Oswestry, so, too, St Carannog was brought in error to Carhampton.

If the case here put forward is valid, it has implications for hagiology and Arthurian Studies alike. There seem to be seven of them. First, the account of the altar's second voyage, which is brief and perfunctory, occupying a mere six lines in Wade-Evans's text, can be seen as a duplicate. Second, we can therefore rule out an original connection of Carannog (as also Cadwy and Arthur) with Somerset. Third, Din Draithou cannot possibly have been Dunster "Dunn's Torr, Dunn's Rock" a mile west of Carhampton. Fourth, Carannog's missionary work, which is probably historic, can be placed in Cornwall. His monastery at Crantock would be two miles west-south-west of Trevelgue, which the excavations of 1939 showed as a centre of local political power in the fifth and sixth centuries, and which possessed an excellent natural harbour on a coast with few such. This part of Cornwall was a focus of sea routes with Wales and Ireland as late as the eighteenth century, indicating that the missionary work of Carannog in south-west Wales and County Meath will be no legend. His movements correspond very well with historical geography. If we reject his activity in Somerset, we can be more confident about Ceredigion, Cornwall, and Meath.

Fifth, the court of Arthur. Despite the pictureque fantasy of Carannog's leading a dragon "like a lamb" into his hall, with his stole around its neck, we can be certain that this was a real place and that it was where the historical Carannog would have negotiated for a grant of land to found a monastery at Crantock, two miles away. In sixth-century Cornwall, Church and State were near neighbours. True, the place had nothing to do with Arthur. He will have been a hero of the North Britons, fighting his battles there and being killed at Camlan (on Hadrian's Wall) in 537, as was consistently argued by Bromwich (1978: 274-276, 544-545). But it may well have been a stronghold of Cato or Cadwy, known as a ruler in south-west Britain. Cadwy was a son of Geraint, son of Erbin, son of Constantine, perhaps the ruler denounced by Gildas in 536 (Bromwich, Evans 1992: 71, 80-81). If the genealogical tradition is sound, it puts Cadwy (and apparently Carannog) at the end of the sixth century, although one notes how Cadwy is supplanted in the vita prima by the more glamorous figure of Arthur. It is still reasonable to accept him as King of Dumnonia with whom the real St Carannog dealt at Trevelgue in the sixth century.

Sixth, the fame of Trevelgue. Thomas in 1994 firmly denied the oft-repeated supposition that Din Draithou of the life, Cair Draithou of Historia Brittonum, and Dind Tradui were the same place. He preferred to take the last as Moel Trigarn, a hill-fort some seven miles south of Cardigan in south-west Wales (Houlder 1974: 180). He has no case. Trevelgue is known otherwise as a centre of power in Early Christian Britain; Moel Trigarn has no such reputation. The first was easily reached by sea from southern Ireland, where Bishop Cormac was writing; the second, some 1200 feet up, was not so. Tradui cannot be explained from Trigarn ('three cairns'); it is readily explained as an Irish version of Brittonic traithou 'beaches', the two long strands between which Trevelgue is situated. This leads to our seventh and final point. 
Irish settlements of the fifth and sixth centuries in west Britain have been studied by Charles-Edwards (2013), who provides a map of inscriptions discovered there and written in ogham script. The locations of these monuments form a band from north-east Cornwall to south-west Devon, which Charles-Edwards regards as "likely to indicate the area of the main Irish settlement" (Charles-Edwards 2013: 168). He draws attention as well to other inscriptions, in Roman script but with Irish names, such as that of Ulcagnus at Nanscow, ten miles east-north-east of Trevelgue (Charles-Edwards 2013: 169). Although it is not credible that Dind Tradui was built by Crimthann in the fourth century, it is credible that the place was for a time an Irish stronghold. That is why it was remembered in Ireland even in the ninth century, when (as proposed by Dark in 1994) it had been abandoned for centuries.

Now for a postscript. Since this paper was written, Higham of Manchester has published a study of King Arthur with comments on his role in the Latin life of Carannog. Higham is, unfortunately, misled by Padel's book on Arthur, and so speaks of land-grants at Carhampton, "which would seem to place the action in Somerset" from which it moves west to Cornwall (Higham 2018: 242). How long it takes to rid historians and others of their delusions. Somerset is a red herring here. The action is purely Cornish, and thereby tells us something of royal authority and prestige in early Christian Cornwall.

In the light of the above, then, we can understand the "Diudraithov" printed in 1680 for Acta Sanctorum as Din Draithou 'stronghold of beaches'; recognize it as the cliff-fort of Trevelgue, situated between two long beaches north of Newquay, Cornwall; and relate it as a centre of political power to Crantock, south of Newquay. Once we dismiss the fairy-tale accretions of Arthur and the dragon, we are left with authentic traditions in vita prima of Carannog's establishment of a monastery near the capital of Dumnonia, where he was presumably granted land in the sixth century by its king, Cato or Cadwy, son of Gerontius or Geraint.

As an appendix, we give the Historia Brittonum list of Britain's Twenty-Eight Cities, with emended Old Welsh forms and locations. They fall into three catagories. Winchester, Carlisle, York, and the like were Roman cities in the normal sense. More obscure are such places as Welsh Bicknor, Doward, and Trellech, all of them monasteries (some of them seats of bishops) in south-east Wales and the border. Cair Draithout or Trevelva belongs to a third group, of British strongholds like Craig Gwrtheyrn, Dumbarton, Caradog, or Dinas Powys. These were all post-Roman secular sites (not ecclesiastical ones), which in different ways were remembered in British tradition and beyond.

\section{Table of identifications}

1. Cair Guorthigirn

2. Cair Guintguic

3. Cair Mingui

4. Cair Ligualid
Craig Gwrtheyrn, Carmarthenshire

Winchester, Hampshire

Monmouth, Monmouthshire

Carlisle, Cumbria 


$\begin{array}{ll}\text { 5. Cair Medgaut } & \text { Lindisfarne, Northumberland } \\ \text { 6. Cair Clut } & \text { Dumbarton, West Dumbartonshire } \\ \text { 7. Cair Ebrauc } & \text { York, North Yorkshire } \\ \text { 8. Cair Custenhin } & \text { Welsh Bicknor, Herefordshire } \\ \text { 9. Cair Caratauc } & \text { Caradog, Herefordshire } \\ \text { 10. Cair Douarth } & \text { Doward, Herefordshire } \\ \text { 11. Cair Fauguid } & \text { Hereford, Herefordshire } \\ \text { 12. Cair Lunden } & \text { London, Greater London } \\ \text { 13. Cair Ceint } & \text { Canterbury, Kent } \\ \text { 14. Cair Guiragon } & \text { Worcester, Worcestershire } \\ \text { 15. Cair Pouis } & \text { Dinas Powys, Vale of Glamorgan } \\ \text { 16. Cair Dam } & \text { Cardiff, Cardiff } \\ \text { 17. Cair Legion } & \text { Chester, Cheshire } \\ \text { 18. Cair Guidcon } & \text { Trellech Grange, Monmouthshire } \\ \text { 19. Cair Segeint } & \text { Caernarfon, Gwynedd } \\ \text { 20. Cair Legion Guar Uisc } & \text { Caerleon, Newport } \\ \text { 21. Cair Guent } & \text { Caerwent, Monmouthshire } \\ \text { 22. Cair Uyrtin } & \text { Carmarthen, Carmarthenshire } \\ \text { 23. Cair Cerion } & \text { Much Dewchurch, Herefordshire } \\ \text { 24. Cair Draithou } & \text { Trevelgue, Cornwall } \\ \text { 25. Cair Pentaloch } & \text { Kirkintilloch, East Dunbarton } \\ \text { 26. Cair Cinmarc } & \text { St Kinemark, Chepstow } \\ \text { 27. Cair Cel Einion } & \text { Llandogo, Monmouthshire } \\ \text { 28. Cair Luit Coyt } & \text { Lichfield, Staffordshire }\end{array}$

\section{References}

Acta Sanctorum $1680=$ Acta Sanctorum Maii. 1680. [vol. 3]. Antverpiae. Alcock L. 1971. Arthur's Britain. London.

Ashe G. 1957. King Arthur's Avalon: The story of Glastonbury. London.

Ashe G. 1968. The Arthurian Fact. - Ashe G. (ed.). The quest for Arthur's Britain. London: 27-57.

Aurell M. 2007. La Légende du roi Arthur. Paris.

Baring-Gould S., Fisher J. 1907-1913. Lives of the British saints. [vol. 2]. London.

Bartrum P.C. 1966. Eary Welsh genealogical tracts. Cardiff.

Bowen E.G. 1954. The settlements of the Celtic saints in Wales. Cardiff.

Bowen E.G. 1972. Britain and the western seaways. London.

Bowen E.G. 1977. Saints, seaways, and settlements in the Celtic lands. [2 ${ }^{\text {nd }}$ edition]. Cardiff.

Breeze A. 2011. Arthur in early saints' lives. - Echard S. (ed.). The Arthur of Medieval Latin literature. Cardiff: $26-41$.

Bromwich R. 1978. Trioedd Ynys Prydain. [2 ${ }^{\text {nd }}$ edition]. Cardiff.

Bromwich R., Evans D.S. (eds.). 1992. Culhwch and Olwen. Cardiff.

Byrne F.J. 1973. Irish kings and high-kings. London.

Carney J. (ed.). 1943. Topographical poems. Dublin.

Carney J. 1955. Studies in Irish literature and history. Dublin. 
Carrera A., Carrera M.J. 2009. Philip Perry's sketch of the ancient British history. Newcastle upon Tyne.

Chadwick H.M. 1954. The foundation of the early British kingdoms. - Chadwick N.K. (ed.). Studies in early British history. Cambridge: 47-60.

Chadwick H.M., Chadwick N.K. 1932. The Growth of literature: The ancient literatures of Europe. Cambridge.

Chadwick N.K. 1958. Intellectual life in West Wales in the last days of the Celtic Church. Chadwick N.K. (ed.). Studies in the early British Church. Cambridge: 29-120.

Chambers E.K. 1927. Arthur of Britain. London.

Charles-Edwards T. 2013. Wales and the Britons 350-1064. Oxford.

Chaussy Y. 1950. Carannog, S. - G. Jacquemet (ed.). Catholicisme hier, aujourd'hui, demain. [vol. 2]. Paris: [cc.] 528-529.

Dark K.R. 1994. Civitas to kingdom. Leicester.

Davies P. 1966. Rhwng Chwedl a Chredo. Caerdydd.

Doble G.H. 1932. St Carantoc. [2 $2^{\text {nd }}$ edition]. Shipston-on-Stour.

Doble G.H. 1971. Saint Illtud. - Evans D.S. (ed.). Lives of the Welsh saints. Cardiff: 135 n.119.

Dumville D.N. 1993. Saint Patrick. Woodbridge.

Elliott-Binns L.E. 1955. Medieval Cornwall. London.

Farmer D.H. 1987. The Oxford dictionary of saints. [2 ${ }^{\text {nd }}$ edition]. Oxford.

FitzPatrick-Matthews K.F. 2015. The XXVIII Civitates Britanniae of the Historia Brittonum: Antiquarian speculation in Early Medieval Wales. - Journal of Literary Onomastics 4: 1-19.

Foster I.Ll. 1935-1937. Penrhyn Pengwaedd a Dinsol. - The Bulletin of the Board of Celtic Studies 8: 23-25.

Fox A. 1973. South-West Britain $3500 B C-A D$ 600. [2 $2^{\text {nd }}$ edition]. Newton Abbot.

Gelling M. 1978. Sign-posts to the past. London.

Gwynn A., Hadcock R.N. 1970. Medieval religious houses: Ireland. London.

Haddan A.W., Stubbs W. 1869-1871. Councils and ecclesiastical documents relating to Great Britain and Ireland. [vol. 1]. Oxford.

Higham N.J. 2002. King Arthur: Myth-making and history. London.

Higham N.J. 2018. King Arthur: The making of the legend. New Haven.

Hogan E. 1910. Onomasticon Goedelicum. Dublin.

Houlder C. 1974. Wales: An archaeological guide. London.

Jackson K.H. 1938. Nennius and the twenty-eight cities of Britain. - Antiquity 12: 44-55.

Jackson K.H. 1953. Language and history in Early Britain. Edinburgh.

Jackson K.H. 1959. The Arthur of history. - Loomis R.S. (ed.). Arthurian literature in the Middle Ages. Oxford.

James J.W. (ed.). 1967. Rhigyfarch's life of St David. Cardiff.

Jankulak K. 2007. Carantoc alias Cairnech?: British saints, Irish saints, and the Irish in Wales. - Jankulak K., Wooding J.M. (eds.). Ireland and Wales and the Middle Ages. Dublin: 116-148.

Jankulak K. 2009. Adjacent saints' dedications and Early Celtic history. - Boardman S., Davies J.R., Williamson E. (eds.). Saints' cults in the Celtic world. Woodbridge: 91-118.

Kenney J.F. 1929. The sources for the early history of Ireland: Ecclesiastical. New York.

Koch J.T. 2007. An atlas for Celtic studies. Oxford.

Lapidge M., Sharpe R. 1985. A bibliography of Celtic-Latin literature. Dublin.

Leland J. 1774. De Rebus Britannicis Collectanea. [2 ${ }^{\text {nd }}$ edition; vol. 3]. Londini.

Lloyd J.E. 1911. A history of Wales. London.

Lloyd J.E. 1937. The story of Ceredigion. Cardiff. 
Lloyd J.E. 1959. Carannog. - [Anonymous]. The dictionary of Welsh biography. London: 67. Lloyd-Jones J. 1931-1963. Geirfa Barddoniaeth Gynnar Gymraeg. Caerdydd.

Lot F. 1900. Nouvelles études sur la provenance du cycle arthurien: Arthur en Cornwall. Romania 30: 1-10.

Map $1966=$ [Anonymous]. Map of Britain in the Dark Ages. 1966. [2 ${ }^{\text {nd }}$ edition]. Southampton. Morris J. 1973. The age of Arthur. London.

Morris J. (ed.). 1980. British history and the Welsh annals. Chichester.

Mostardi F. 1962. Carantoco. - [Anonymous]. Bibliotheca Sanctorum. [vol. 2]. Roma: [cc.] 779-780.

Needham G.I. (ed.). 1966. Lives of three English saints. London.

O'Rahilly T.F. 1946. Early Irish history and mythology. Dublin.

Owen H.W., Morgan R. 2007. Dictionary of the place-names of Wales. Llandysul.

Padel O.J. 1988. A popular dictionary of Cornish place-names. Penzance.

Padel O.J. 1994. The nature of Arthur. - Cambrian Medieval Celtic Studies 27: 1-31.

Padel O.J. 2013. Writers of Wales: Arthur in medieval Welsh literature. [2 ${ }^{\text {nd }}$ edition]. Cardiff. Pevsner N. 1970. The buildings of England: Cornwall. [2 ${ }^{\text {nd }}$ edition]. London.

Plummer C. (ed.). 1910. Vitae Sanctorum Hiberniae. Oxonii.

Plummer C. 1925. Miscellanea Hagiographica Hibernica. Bruxelles.

Rees W.J. (ed.). 1853. The lives of the Cambro-British saints. Llandovery.

Thomas C. 1994. And shall these mute stones speak? Cardiff.

Torres Asensio G. 2003. Los orígenes de la literatura artúrica. Barcelona.

Vies des Saints 1936-1957 = Vies des Saints et des Bienheureux. 1936-1957. [vol. 5]. Paris.

Wade-Evans A.W. (ed.). 1944. Vitae Sanctorum Britanniae. Cardiff.

Watson W.J. 1926. The history of the Celtic place-names of Scotland. Edinburgh.

Watts V. (ed.). 2004. The Cambridge dictionary of English place-names. Cambridge.

Wickham-Crowley K.M. 2002. Writing the future. Cardiff.

Williams H. 1912. Christianity in Early Britain. Oxford.

Williams I. 1929-1931. Enwau ac Anryfeddodau Ynys Prydain. - Bulletin of the Board of Celtic Studies 5: 19-24.

Williams I. 1935. Canu Llywarch Hen. Caerdydd. 